\title{
Study on the Influence of Monetary Policy on Real Estate Price in China
}

\author{
Na Yan \\ College of Economics, Jinan University, Guangzhou, China \\ Email: yanna0303@sina.com
}

How to cite this paper: Yan, N. (2019) Study on the Influence of Monetary Policy on Real Estate Price in China. Journal of Service Science and Management, 12, 152-171.

https://doi.org/10.4236/jssm.2019.122011

Received: January 14, 2019

Accepted: February 10, 2019

Published: February 13, 2019

Copyright (c) 2019 by author(s) and Scientific Research Publishing Inc. This work is licensed under the Creative Commons Attribution International License (CC BY 4.0).

http://creativecommons.org/licenses/by/4.0/

\section{(c) (i) Open Access}

\begin{abstract}
The real estate industry has been in a stage of rapid development since 2000, and its pulling effect on economic growth is very significant, but it has continued to develop at a rapid pace over the years. The rising prices that follow have also had a lot of impact on all aspects of society and economy. However, a country's macroeconomic control policy, especially monetary policy, has a very important impact on the development of the real estate industry. For example, the expansionary monetary policy since 2008 has increased the money supply, so that the real estate market investment and consumption rising, house prices accelerated. Although there are also a lot of restrictions of macroeconomic policy on the rise of house prices, the effect is not obvious. Therefore, it is necessary to make use of the policy means to regulate the real estate industry in order to achieve healthy development. This paper first analyzes the mechanism of monetary policy influencing real estate price, and then discusses the effect of monetary policy on real estate market by using empirical research method. It is found that both money supply and interest rate will have an impact on real estate price. Finally, combined with the conclusion of the analysis, some policy suggestions are put forward to improve the monetary policy system for the healthy development of the real estate industry.
\end{abstract}

\section{Keywords}

Monetary Policy, Real Estate Prices, VAR

\section{Introduction}

The real estate industry, as an important industry of our country's economy and society, has the characteristics of long industrial chain, high correlation degree, wide slope and wide range. The self-development of the real estate market can not only promote the progress of other industries, but also the benign develop- 
ment of the real estate industry will make a remarkable contribution to the steady progress of social economy, promote the rationalization and upgrading of industrial structure, and increase the comfort of living. It is very important to perfect the function of the city, optimize the quality of the city, pull the consumption level, promote the employment and promote the comprehensive competition of economy.

Monetary policy refers to the sum of policies and measures by which the central bank adjusts the amount of money supply and the interest rate in order to achieve the established economic objectives and then affects the level of national output. The transmission mechanism of monetary policy describes how monetary policy influences the real economy with the aid of monetary shock and the path on which the effect of monetary policy is implemented. It is the basis of the effectiveness of monetary policy.

Because real estate prices can affect a country's monetary policy system through a series of mechanisms and channels, to a large extent, the change in real estate prices has gradually become a weather vane for a country's macro-economy, as reflected in the fact that a large increase in house prices may mean that there will be high prices and output levels. A large drop in house prices may mark a contraction or even a recession, a link that has been confirmed by many historical practices. Monetary policy is the main means of regulating the macro-economy, so a national product. The currency authorities need to pay close attention to the real estate market if they are to maintain price stability and promote economic stability.

Therefore, it is meaningful to explore the impact of monetary policy on real estate prices. As the most important issue in monetary policy theory, the transmission mechanism of monetary policy discusses how the government of a country uses monetary policy to influence consumption, investment and other factors through various transmission channels such as interest rate, money supply volume, asset price, etc. Finally realize the macro-control of the real economy. The hot and difficult topic of financial research has always been the spread of monetary policy transmission mechanism, which is mainly due to its extremely strong space-time and dynamic nature, and its policy effects will be subject to economic and social conditions. It is necessary to study the transmission mechanism of monetary policy according to the change of economic situation because of the implementation and expected effect of policy system and the influence of financial market and so on. The transmission path and implementation effect of monetary policy in China have been enhanced and expanded because of the new and deep development of the real estate industry. But at the same time, the transmission mechanism and implementation of monetary policy will be complicated by the increase of channels and subjects of monetary policy transmission. From 2012 to 2018, during the implementation of the prudent monetary policy, the domestic housing price showed an obvious rising trend in the fluctuation, and the quarterly average growth rate of housing price in 70 large and medium-sized cities was as high as $10.2 \%$. Therefore, analyzing the real 
estate price transmission mechanism of monetary policy and exploring how to effectively exert the function of monetary policy in guiding and regulating the real estate industry has become a very urgent research content.

Over the years, as an important industry supporting the national economy, the real estate market prices have been rising steadily, even though the real estate prices fluctuated during the financial crisis of 2008, the real estate market has highlighted the characteristics of its instability. But its role in the social economy is still increasingly important. From the macro and micro levels, the rapid rise of real estate prices will bring a lot of negative effects to the economy and society. From the macro level: first, because of the wealth effect and the transmission of the industrial chain, high real estate prices may induce inflation. Second, the effect of monetary policy will be weakened by rising property prices. At the micro-level: overinflated property prices threaten residents' residency rights.

\section{Journals Reviewed}

At present, many scholars at home and abroad have conducted researches on the transmission path of monetary policy to real estate price. This paper sorts out the foreign literature and domestic literature respectively.

\subsection{A Review of Relevant Foreign Documents}

The theory of analyzing the relationship between monetary policy and real estate price originates from the theory of asset price fluctuation. The role of real estate in the transmission mechanism of monetary policy in the United States, and found that real estate prices play a very important role in the transmission mechanism of monetary policy after considering the factors of the same period [1]. The effect of stock price on the transmission of monetary policy is not significant [2]. Finally, it is concluded that the real estate price has a great impact on the economy, but because the market changes are very difficult to figure out, it is proposed that only when the real estate price affects the future output and employment, can the real estate price interfere with it, otherwise, the market behavior will be believed. The structural VAR model was used to test the medium-term and short-term constraints, and it was found that the fluctuation of real estate prices affected consumption, prices and interest rates [3]. In recent years, the government, the central bank and the academic community have all worked together to study how monetary policy should react to the changes in real estate prices. However, the research on the real estate price transmission mechanism of monetary policy is still in the exploratory stage. In studying the real estate price transmission mechanism of monetary policy, most foreign scholars do not study the transmission process as a whole, but discuss the two links in the transmission process separately. Otherwise, only a special channel or effect is discussed in depth, and the conclusion of the research is given. In the analysis of monetary policy on the regulation of real estate prices, foreign scholars mainly from the interest rate approach, credit path and portfolio effect ap- 
proach to research.

In the analysis of interest rate approach, Abraham \& Hendershott uses a model of housing price change considering lag process to reveal that the rise of housing price is negatively correlated with interest rate [4]. Iwayama, Akiyama \& Ishigaki established a VAR model to study the impact of British monetary policy on the real estate market [5]. It was found that after the interest rate rose by 50 basis points, house prices in the UK fell 0.8 percent in five quarters, similar to the reaction of consumer durable goods. The influence of interest rate and real estate price is unidirectional [6]. In the long run, only real estate price has influence on interest rate. Iacoviello \& Minetti analyzed the impact of financial liberalization on the relationship between monetary policy and property prices, and established a simple model for a small open economy under credit constraints [7]. The model shows that the greater the degree of financial freedom, the higher the degree of financial freedom. The greater the impact of interest rates on real estate prices. Nine European countries (Belgium, Finland, France, Ireland, Italy, the Netherlands, Spain) after interest rate rise through a series of VAR models. Real estate prices in Sweden and the UK will fall to varying degrees [8].

In an analysis of credit routes, Collyns et al. found that credit growth had a significant effect on housing prices in many Asian countries over the same period [9]. Iacoviello \& Minetti used three different VECM models and one VAR model to examine the credit channels that monetary policy in four different European countries affected the real estate market [10]. They reasoned that the evidence of banks' credit channels was also evidence of the balance sheet. Davis \& Zhu shows that it is the commercial real estate price that causes the credit expansion through the transnational causality test [11].

In the aspect of portfolio effect, some scholars use panel data to analyze the relationship between real estate price and stock price. For example, Titman \& Q. S. used the annual data of major cities in 17 countries, such as the United States, Britain, France and Germany, to analyze the relationship among stock returns, real estate value and rent [12]. There is a close relationship between real estate value and rent. More scholars use time series data to analyze the relationship between real estate price and stock price. For example, when Wilson \& Okunev carries out unit root and cointegration test and nonlinear regression analysis to the monthly data of the United States, it is found that there is a nonlinear relationship between the real estate market and the stock market [13], but not significantly. Chen \& Nan K using the quarterly data of Taiwan, China, we made an empirical analysis of the stock price and the housing price, and found that the assets [14]. The initial impact of the rise in prices eventually led to the interaction of real estate prices and stock prices to form a spiral-up trend. Real estate and equity are the main assets held by private and institutions, and their price changes represent the main trends in asset price changes.

\subsection{A Review of Domestic Related Research}

In China, the real estate industry is a new development industry, so there was lit- 
tle research on it in our country until recent years. With the development of the real estate market and the unsatisfactory effect of monetary policy on the real estate industry, domestic scholars and the banking system began to pay attention to the real estate price transmission mechanism of monetary policy.

In theoretical analysis, Meng Xing discussed several ways of the transmission of monetary policy to real estate market analyzed the reasons why the transmission effect was not ideal and gave corresponding policy suggestions [15]. Zheng Lan summarized the conclusion of monetary policy on real estate market from three aspects [16]. These three aspects are monetary policy transmission theory, main research methods and the evaluation of monetary and financial policies by scholars from all over the world. Wang J. C. et al. believes that it is difficult for the central bank to use interest rates to regulate real estate prices [17].

In the empirical research, the first is the analysis of credit conduction effect. Xie Jingrong used regression analysis to prove that credit has a strong positive relationship with real estate prices [18]. Pei Shun \& Wu Kangping use ECM model to show that there is a linear causal relationship between the real estate market and the bank credit market in China, and this relationship is bidirectional in both the long and short term [19]. The second is the analysis of the transmission effect of money supply. Zhang Xiangrui using VAR model, argues that the effect of money supply on real estate prices is mainly produced in the long term, not in the short term [20]. The third is the analysis of the conduction effect of interest rate. The third is the analysis of the conduction effect of interest rate. Chen Huai and Zheng Xiang have focused on the influence of various interest rates on house prices, and all hold monetary policies that can affect real estate prices [21]. The effect of interest rate is more obvious than that of money supply. Although some views are contrary, such as Gong Binen, the impact of the change in interest rates on real estate prices is not significant [22]. But in the long run, this effect will be very strong. Although the conclusions vary, monetary policy can affect real estate prices is a common view of scholars.

As can be seen from the above research, foreign scholars have more systematic and extensive research on the real estate price conduction mechanism of monetary policy, and the analysis of different countries, the result is more diversified, and the existence of the real estate price conduction channel of monetary policy is affirmed. The domestic scholars have relatively late research on this subject, and in the early days, it is mainly focused on the introduction of the relevant theoretical results of foreign research. In recent years, with the continuous development of China's real estate market, scholars have reached a consensus on the existence of real estate price transmission channels of monetary policy in China. Variable selection and data range are different, so there are different conclusions.

\section{Theoretical Analysis on the Influence of Monetary Policy on Real Estate Price}

At present, domestic and foreign scholars study the influence of monetary policy 
on real estate price from different transmission paths. This paper is organized as follows.

\subsection{Interest Rate Channel}

The real estate industry is one of the industries most affected by the change of interest rate. The central bank can adjust the interest rate and influence the behavior of the main bodies in the real estate market, thus causing the change of the relationship between supply and demand, and then affecting the real estate price. Here is an example of raising interest rates to illustrate how the main parties react.

\subsubsection{The Influence of Raising Interest Rate on Real Estate Development Enterprises}

For real estate developers, raising interest rates increases the cost of development, which will eventually be recorded in real estate prices, but that does not necessarily lead to higher real estate prices. Because real estate prices are also affected by other factors, ultimately depends on the real estate supply and demand balance. For small development enterprises, because of the increase in costs and the crisis in the capital chain, there is an urgent need to withdraw funds. It may be possible to lower the sales price for large development enterprises with strong capital strength, and it is possible to pass on this part of the cost to consumers. Raising the sales price is also possible to develop companies to reduce profit margins and maintain the original sales price. But in general, raising interest rate increases the cost of real estate development enterprises, and the result of raising interest rates to a certain extent may make real estate development enterprises face reshuffle. This conduction can be summarized as:

Interest rate $\uparrow \rightarrow$ development cost $\uparrow \rightarrow$ real estate supply $\downarrow \rightarrow$ real estate prices $\uparrow$

\subsubsection{The Impact of Raising Interest Rates on Homebuyers}

The real estate is a kind of high price special commodity, most buyers cannot make a one-time payment, more use the way of mortgage to purchase, with the purchase of the property as collateral, apply to financial institutions or housing provident fund management agencies to purchase loans, and within a certain period of time according to the loan contract to repay the principal and interest. For home buyers, the impact of raising interest rates is far greater than that of real estate development enterprises. The increase in interest rates actually reduces the support of banks for home buyers, thereby reducing the ability of buyers to pay. The decline in purchasing power is bound to lead to a gradual decline in overall market demand. With higher interest rates, higher mortgage payments and higher home costs, some buyers will pull out of the housing market, and falling demand will cause property prices to fall. Higher interest rates also lower the real price-to-income ratio, which if income stays the same, real house prices will fall. If the real estate price does not reduce, then the income must increase, only then can afford the corresponding house price. If income does not change, 
those with low marginal ability to pay must be excluded, with the result that demand will also be reduced. But in fact, if interest rates are not too large, the impact on home buyers demand is limited. This conduction can be summarized as:

The interest rate $\uparrow \rightarrow$ the amount of the loan $\uparrow \rightarrow$ the cost of buying a house $\uparrow$ $\rightarrow$ the demand for real estate $\downarrow \rightarrow$ the real estate price $\downarrow$

\subsubsection{The Impact of Higher Interest Rates on Investors}

For investors, the impact on the return on investment is still significant, even if interest rate increases are modest. Raising interest rates increases speculative costs to a certain extent and will inevitably lead to less demand for investment. Speculators are likely to turn to other industries, or hold money to buy, and to a certain extent stifle demand for real estate. However, while restraining speculative demand, this measure also inhibits the normal investment demand and the housing consumption demand of low- and middle-income groups, and the real demand for housing is stronger than the demand for investment speculation. Low- and middle-income groups have become the recipients of high house prices. This conduction can be summarized as:

interest rate $\uparrow \rightarrow$ Speculative cost $\uparrow \rightarrow$ Real estate demand $\downarrow \rightarrow$ Real estate price $\downarrow$

\subsection{Money Supply Channel}

The money supply way also has the scholar to call the credit way. Under the secondary banking system, the central bank changes the money supply by using monetary policy instruments such as open market operations, rediscount, reloans and legal deposit reserves. This will change the reserves and deposits of commercial banks. And then affect its loan supply capacity. The change of bank's loan ability will affect the availability of real estate loan, thus increase or decrease the demand of real estate, and cause the corresponding change of price. If the central bank adopts an expansionary monetary policy, the reserves and deposits of commercial banks will increase, and their ability to make loans will increase, thereby increasing the effective demand for real estate and leading to a rise in real estate prices. This conduction can be summarized as:

currency supply $\uparrow \rightarrow$ real estate loan $\uparrow \rightarrow$ Real estate demand $\uparrow \rightarrow$ Real estate price $\uparrow$

In theory, monetary policy determines the money supply. There are two kinds of effects of money supply on real estate price. One is the increase of money supply. The change of money supply will ultimately influence other variables by influencing interest rate to guide the supply and demand of real estate market. Similar to the interest rate mechanism, the influence of the change of money supply on the real estate price also depends on the behavior choice of various agents in the real estate market. However, interest rate has not been completely marketized in our country, so the change of money supply will not function entirely through the interest rate mechanism. Second, the increase in the money supply may cause inflation. When the money supply increases, people use excess money to spend, causing prices to rise, including the price of financial assets and 
the price of real assets. This effect can be direct, such as the direct use of money to buy real estate can be indirect, through building materials and other prices such as rise in house prices. As a result of inflation expectations, people tend to invest to preserve their value, increasing the investment demand for real estate, increasing the price of real estate, raising the level of money costs of real estate developers, and moving up the supply curve. Real estate equilibrium prices will also rise.

\section{An empirical Analysis of the Impact of Monetary Policy on Real Estate Prices}

\subsection{Model Selection}

In the 1970s, Sims established the VAR method. Litterman paper further enhanced the practicality of the VAR method, the whole 1980s VAR method is popular throughout the United States [23]. Over time, the VAR method has been continuously improved in practice from a UVAR, that initially relied entirely on data, without any constraints, to take into account the small sample characteristics of macroeconomic data. An improved BVAR, with some priori constraints on the estimation parameters until the SVAR, with macroeconomic theory as the constraint condition, The VAR method has gained more and more followers and has played an important role in the field of economic prediction. The emergence of the VAR method emphasizes the dynamic characteristics of the economic system. Attention is focused on a smaller range of causal variables.

The general representation of VAR model is: $y_{t}=A_{1} y_{t-1}+\ldots+A_{p} y_{t-p}+B X_{t}+\varepsilon_{t}$ $(t=1,2, \ldots T), y_{t}$ is a $k$-dimensional endogenous variable vector, $X_{t}$ is a dimensional exogenous variable vector, $\mathrm{p}$ is a lag order, and the number of samples is $T . k \times k$ dimensional matrix A_1N. $A_{p}$ and $k$ dimensional matrix $B$ are coefficient matrices to be estimated. $\varepsilon_{t}$ is a k-dimensional perturbation vector, and they can correlate directly with each other in the same time, but not with their own lag values or with the variables on the right side of the equation.

The upper expression can be expressed as a matrix:

$$
\left(\begin{array}{c}
y_{1 t} \\
y_{2 t} \\
\ldots \\
y_{k t}
\end{array}\right)=A_{1}\left(\begin{array}{c}
y_{1 t-1} \\
y_{2 t-2} \\
\ldots \\
y_{k t-1}
\end{array}\right)+A_{2}\left(\begin{array}{c}
y_{1 t-1} \\
y_{2 t-2} \\
\ldots \\
y_{k t-2}
\end{array}\right)+\ldots+B\left(\begin{array}{c}
x_{1 t} \\
x_{2 t} \\
\ldots \\
x_{k t}
\end{array}\right)+\left(\begin{array}{c}
\varepsilon_{1 t} \\
\varepsilon_{2 t} \\
\ldots \\
\varepsilon_{k t}
\end{array}\right), t=1,2, \ldots T
$$

If the VAR model does not contain exogenous variables, it can be expressed as: $y_{t}=A_{1} y_{t-1}+\ldots+A_{p} y_{t-p}+\varepsilon_{t}$ or $A(L) y_{t}=\varepsilon_{t}$, where $A(L)=I_{k}-A_{1} L-A_{2} L^{2}-\ldots-A_{p} L^{p}$, the parameter matrix of $K \times K$ of the delay operator $L$. This expression is generally referred to as the non-restrictive vector autoregressive model. The shock vector $\varepsilon_{t}$ is a white noise vector because $\varepsilon_{t}$ has no structural meaning and is called a simplified form of shock vector.

\subsection{Variable Selection and Data Sources}

Combining the two factors of variables selection and data availability, the fol- 
lowing monthly data are selected as the study variables in this paper. The time span is from February 2009 to October 2017.

\subsubsection{Monetary Policy Level: Money Supply, Interest Rate as the Representative Variable}

In this paper, the controllable and measurable target of monetary intermediation is chosen as the variable of monetary policy. The choice of intermediate target is the key link of an effective monetary policy framework. Theoretically and practically, the choice of this goal is mainly focused on the choice of money supply and interest rate.

1) Use broad money supply to represent money supply (expressed in M2)

M0 only represents cash in circulation, and that the scope is too narrow. M1 mainly reflects the impact of money supply on the economy from the perspective of realistic demand. M2 not only reflects the influence of money supply on economy from the point of view of demand, but also reflects the relationship between money supply and economy from the aspect of supply, because the savings deposit contained in M2 is an important source of enterprise investment funds. Ding Chen and in 1998, the loan scale was abolished, making money supply the sole intermediate target of monetary policy. Although in 1998 the central bank formally took the money supply as the intermediate target of monetary policy, and at the same time took M0/M2 as the observation target, with the continuous development of the economy and the acceleration of the pace of financial innovation, M1 increasingly showed the shortcoming of insufficient controllability. The controllability of M2 is relatively strong, and more views tend to use M2 instead of M1 as an intermediary of monetary policy target .In view of this, this paper chooses the broad money supply M2 to represent the money supply in the monetary policy indicator variable.

2) The average interest rate of 90 days in the interbank market represents the interest rate (expressed in RATE)

The average interest rate of 90 days in the interbank market is chosen as the interest rate in the indicative variable of monetary policy.

\subsubsection{The Choice of Real Estate Price Representative Variable}

Real estate prices are represented by the national average selling price of commercial housing (expressed in HP).

Because the real estate sale price of the whole country cannot be found, there are various kinds of real estate index, such as the middle house index, the national house index and so on, which have their own defects in the data collection and compilation method, and the data are not comparable horizontally and vertically. And there is no fixed base sales price index. This paper adopted the national commercial housing sales/the national commercial housing sales area to represent the national average real estate sales price. However, due to the lack of annual January data on the national commercial housing sales and the national commercial housing sales area, only February 2009 to February 2009 were retained in the processing process. Data are from February to December of each 
year in the middle of October, 2007.

The research data are mainly from the China Economic and Social Development Statistics Database, the National Bureau of Statistics of China, the people's Bank of China and Guotai'an CSMAR database. The software used in this paper is the economic quantitative analysis software Eviews8.0.

\subsection{Processing and Testing of Variables}

For the three variables selected, the national average sales price of real estate is divided by the monthly data of the national commercial housing sales and sales area. In order to eliminate the heteroscedasticity in time series and avoid the fluctuation of data, the logarithmic method should be used to obtain LNM2, LNRATE and LNHP.

\subsubsection{Stationary Test}

There are usually graphical method and unit root test method for the test of sequence stationarity. Among them, the unit root test includes three kinds: DF test, ADF test and PP test. In this paper, the ADF test method is adopted. Its basic principle is that the test of the stationary property of time series is essentially the test of unit root, if there is unit root in non-stationary time series, Then the non-stationary time series can be transformed into stationary series by using difference method, so that the corresponding research can be carried out by using the method of stationary time series. For time series in which unit roots exist, they generally show obvious memory and volatility persistence. Therefore, the results of unit root test must be used to confirm that each variable is a sequence with the same order before cointegration test in order to carry out cointegration test.

After examining LNM2, LNRATE and LNHP, the results are shown in the table.

From Table 1, we can see that sequence LNM2 is stationary sequence, sequence LNRATE and LNHP are non-stationary sequence, but after first order difference, DLNRATE and DLNHP reject the original hypothesis at $1 \%$ confidence level, that is, stationary sequence.

\subsubsection{Determination of Lag Order}

The larger the lag order is, the more complete the dynamic characteristics of the model are, but the more the estimated parameters are, the less the degree of freedom of the model is and the effectiveness of the parameters is affected. The results of calculating the statistics and obtaining the order of lag show that three of the five statistics think that the VAR (2) model should be established, and then the VAR (2) model is established as Table 2.

\subsubsection{Granger Causality Test}

The Granger causality test mainly analyzes whether the lag term of a variable can affect other variables. If a variable is really affected by the term after other variables, it is said that there is a Granger cause-oriented relationship between 
Table 1. ADF test results.

\begin{tabular}{ccccccc}
\hline Variable & ADF value & $\begin{array}{c}\text { Type of inspection } \\
(\mathrm{c}, \mathrm{t}, \mathrm{l})\end{array}$ & $\begin{array}{c}1 \% \text { critical } \\
\text { value }\end{array}$ & $\begin{array}{c}5 \% \text { critical } \\
\text { value }\end{array}$ & p value & $\begin{array}{c}\text { Smooth } \\
\text { or not }\end{array}$ \\
\hline LNM2 & -3.37773 & $(\mathrm{c}, 0,0)$ & -3.50928 & -2.89592 & 0.0145 & Yes \\
LNRATE & -2.36374 & $(\mathrm{c}, 0,0)$ & -3.49991 & -2.89187 & 0.1547 & No \\
DLNRATE & -10.80210 & $(\mathrm{c}, \mathrm{t}, 0)$ & -4.05752 & -3.45781 & 0.0000 & Yes \\
LNHP & -0.24385 & $(\mathrm{c}, 0,0)$ & -3.50928 & -2.58517 & 0.9276 & No \\
D LNHP & -3.61092 & $(\mathrm{c}, \mathrm{t}, 0)$ & -4.06963 & -3.46355 & 0.0348 & Yes \\
\hline
\end{tabular}

Note: (1) D is the first order difference; 2 , in the form of test, $(c, t, 1)$ denotes the constant term, the time trend term and the lag order in the ADF test model, respectively.

Table 2. VAR model lag selection.

\begin{tabular}{ccccccc}
\hline Lag order & LogL & LR & FPE & AIC & SC & HQ \\
\hline 0 & 108.0699 & NA & $2.20 \mathrm{e}-05$ & -2.21199 & -2.131348 & -2.179409 \\
1 & 535.7776 & 819.3979 & $3.26 \mathrm{e}-09$ & -11.0269 & -10.70430 & -10.89654 \\
2 & 558.9296 & $42.89213^{*}$ & $2.42 \mathrm{e}-09^{*}$ & $-11.3248^{*}$ & -10.76029 & -11.09672 \\
\hline
\end{tabular}

Note: ${ }^{*}$ represents significant at the $5 \%$ level.

them. Table 3 shows the results of the Granger causality test of real estate prices and monetary policy factors in the VAR model.

From Table 3: 1) there is a two-way Granger causality between money supply and real estate price. Money supply can cause real estate price to change, and the effect is obvious. And real estate prices can also cause changes in the money supply. And the change of M2 growth rate is more reflected in the change in real estate prices. As far as the impact of real estate prices on money supply is concerned, changes in real estate prices will not cause changes in M1 growth, but will cause changes in M2 growth. However, there are few literatures about the influence of real estate price on the money supply and the transmission mechanism, which still needs to be studied; 2) interest rate is not the Granger cause of real estate price, but the test $\mathrm{p}$ value of LNRATE to LNHP is 0.2153 , which indicates that interest rate still has influence on real estate price, but the effect is not obvious. This is not consistent with the previous theoretical analysis, mainly because of the delay in the transmission mechanism of interest rates, the control of interest rates by the state, and the fact that China has not really realized the marketization completely. The real price of funds cannot be expressed through the loan interest rate, so the effect of interest rate on the real estate price is limited; 3) there is no causal relationship between money supply M2 and interest rate, that is, there is no influence on each other, which indicates that China's monetary policy is independent.

\subsection{Stability Test and Parameter Estimation Results}

\subsubsection{Stability Test}

In order to ensure the validity of impulse response function analysis, the estimated 
Table 3. Granger causality test for VAR model.

\begin{tabular}{ccccc}
\hline $\begin{array}{c}\text { Dependent } \\
\text { variable }\end{array}$ & $\begin{array}{c}\text { Independent } \\
\text { variable }\end{array}$ & F statistic & p value & $\begin{array}{c}\text { Whether to reject the } \\
\text { original hypothesis }\end{array}$ \\
\hline \multirow{2}{*}{ LNHP } & LNM2 & 22.85464 & 0.0000 & Yes \\
& LMRATE & 2.204349 & 0.3321 & No \\
LNM2 & LNHP & 18.06086 & 0.0001 & Yes \\
& LNRATE & 4.449724 & 0.1081 & No \\
LNRATE & LNHP & 3.071537 & 0.2153 & No \\
& LNM2 & 1.548914 & 0.4610 & No \\
\hline
\end{tabular}

VAR model should be tested for stability first. The so-called stability test is when a pulsating shock is applied to the innovation of a certain equation in the VAR model. Over time, analyze whether this shock will gradually disappear. As Table 4 and Figure 1, the following AR root diagram that no root is outside the unit circle and the modulus of the characteristic root is less than 1, so the model set in this paper satisfies the stability condition and the result of the impulse response function obtained is robust and reliable.

\subsubsection{Parameter Estimation Results of VAR Model}

Rewrite the VAR (2) model of Table 4 \& Table 5 into matrix form:

$$
\begin{aligned}
{\left[\begin{array}{c}
\text { LNHP }_{t} \\
\text { LNM2 }_{t} \\
\text { LNRATE }_{t}
\end{array}\right] } & =\left[\begin{array}{ccc}
0.8812 & 0.1955 & -0.0057 \\
0.1030 & 0.8574 & -0.0213 \\
0.9343 & -0.3533 & -0.7932
\end{array}\right]\left[\begin{array}{c}
\mathrm{LNHP}_{t-1} \\
\mathrm{LNM}_{t-1} \\
\mathrm{LNRATE}_{t-1}
\end{array}\right] \\
& +\left[\begin{array}{ccc}
0.0221 & -0.1467 & 0.0003 \\
-0.1016 & 0.1309 & 0.0213 \\
-0.1197 & -0.0609 & 0.1509
\end{array}\right]\left[\begin{array}{c}
L N H P_{t-2} \\
L N M_{t-2} \\
L^{2} R A E_{t-2}
\end{array}\right]+\left[\begin{array}{c}
0.1734 \\
0.1597 \\
-1.2935
\end{array}\right]
\end{aligned}
$$

Tables 5-7 are the parameter estimation result of the regression equation of VAR model. From the equation, we can clearly see the impact of various factors on real estate prices.

\subsection{Empirical Test and Analysis}

\subsubsection{Empirical Test and Analysis of Real Estate Price on Monetary Policy \\ 1) Impulse response function}

As you can see from Figure 2, when a unit of money supply LNM2 is positively impacted in the current period, it acts quickly in the real estate market, producing a positive impact, and reaches a temporary peak in Phase 2 (0.0017), with a slight decline in Phase 3. Then it recovered gradually, showing a positive and stable growth, reaching about $0.36 \%$ in the 20 th period. It shows that the change of money supply has a long-term effect on real estate prices. It can be seen from the analysis that when the external environment exerts a certain impact on the money supply, the impact of this impact will pass through the market to the real estate industry and bring it a shock in the same direction. And the impact on real estate prices to pull more obvious, and longer duration. 
Table 4. Root table of AR characteristic polynomials.

\begin{tabular}{cl}
\hline Root & Modulus \\
\hline 0.989753 & 0.989753 \\
0.920190 & 0.920190 \\
0.558282 & 0.558282 \\
-0.385870 & 0.385870 \\
0.293421 & 0.293421 \\
-0.213157 & 0.213157 \\
\hline
\end{tabular}

No root lies outside the unit circle. VAR satisfies the stability condition.

Table 5. VAR model parameter estimation results.

\begin{tabular}{cccc}
\hline & LNHP & LNM2 & LNRATE \\
\hline LNHP (-1) & 0.881180 & 0.103038 & 0.934337 \\
& $(0.07739)$ & $(0.07368)$ & $(1.01109)$ \\
LNHP (-2) & {$[11.3857]$} & {$[1.39854]$} & {$[0.92409]$} \\
& 0.022055 & -0.101599 & -0.119736 \\
& $(0.05956)$ & $(0.05670)$ & $(0.77812)$ \\
LNM2 (-1) & {$[0.37029]$} & {$[-1.79188]$} & {$[-0.15388]$} \\
& 0.195478 & 0.857431 & -0.353256 \\
LNM2 (-2) & $(0.11434)$ & $(0.10885)$ & $(1.49377)$ \\
& {$[1.70962]$} & {$[7.87739]$} & {$[-0.23649]$} \\
LNRATE $(-1)$ & -0.146663 & 0.130943 & -0.060900 \\
& $(0.11459)$ & $(0.10908)$ & $(1.49703)$ \\
& {$[-1.27989]$} & {$[1.20038]$} & {$[-0.04068]$} \\
& -0.005659 & -0.021306 & 0.793150 \\
LNRATE (-2) & $(0.00921)$ & $(0.00877)$ & $(0.12036)$ \\
& {$[-0.61418]$} & {$[-2.42927]$} & {$[6.58966]$} \\
& 0.000276 & 0.021310 & 0.150905 \\
& $(0.00918)$ & $(0.00874)$ & $(0.11996)$ \\
& {$[0.03006]$} & {$[2.43795]$} & {$[1.25800]$} \\
& 0.173419 & 0.159679 & -1.293538 \\
& $(0.09321)$ & $(0.08873)$ & -1.217740 \\
& {$[1.86048]$} & {$[1.79953]$} & {$[-1.06224]$} \\
\hline
\end{tabular}

Table 6. Test results of each equation of VAR model.

\begin{tabular}{cccc}
\hline R-squared & 0.996707 & 0.999292 & 0.895819 \\
\hline Adj.R-squared & 0.996432 & 0.999233 & 0.887137 \\
Sum sq.resids & 0.006945 & 0.006294 & 1.185368 \\
S.E.equation & 0.009821 & 0.009350 & 0.128310 \\
F-statistic & 3631.962000 & 16926.430000 & 103.183700 \\
Log likelihood & 256.800300 & 260.690000 & 53.779930 \\
Akaike AIC & -6.324059 & -6.422532 & -1.184302 \\
Schwarz SC & -6.114108 & -6.212581 & 0.974351 \\
Mean dependent & 8.723066 & 13.825980 & 1.332305 \\
S.D. dependent & 0.164434 & 0.337488 & 0.381930 \\
\hline
\end{tabular}


Table 7. Overall test results of VAR model.

\begin{tabular}{cc}
\hline Determinant resid covariance (dof adj.) & $9.51 \mathrm{E}-11$ \\
Determinant resid covariance & $7.2 \mathrm{E}-11$ \\
Log likelihood & 586.210700 \\
Akaike information criterion & -14.309130 \\
Schwarz criterion & -13.679280 \\
\hline
\end{tabular}

\section{Inverse Roots of AR Characteristic Polynomial}

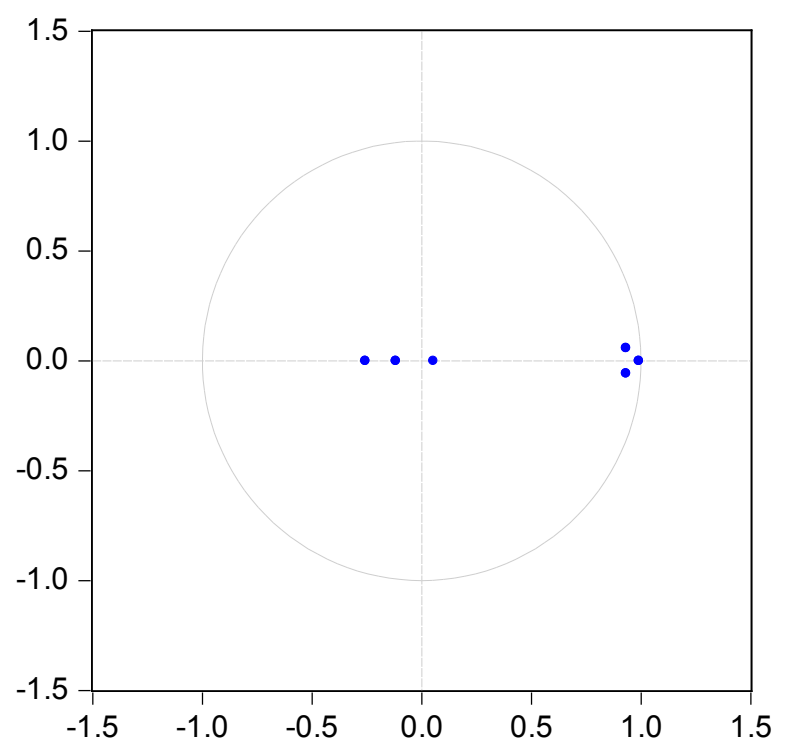

Figure 1. Root graph of characteristic polynomial of AR.

\section{Response of LNHP to Cholesky} One S.D. LNM2 Innovation

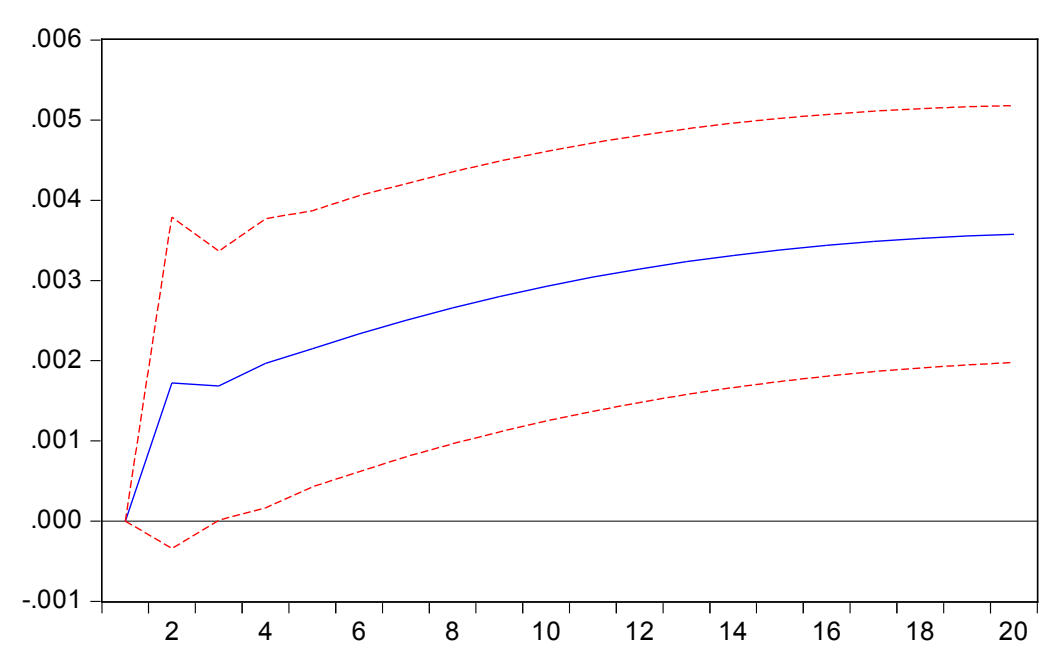

Figure 2. Pulse response diagram of LNHP to LNM2.

As can be seen from Figure 3, after a positive impact on interest rates in the current period, and gradually reflected in the real estate market through various 
paths, real estate prices will show a downward trend, reaching their lowest level in the 12 th issue $(-0.0030)$, and stabilized to the 14 th phase, then gradually upward, in the 20th phase of -0.0025 . Under the impact of interest rate, the fluctuation of real estate price is negative in the long term and lasting for a long time. After that, the effect of interest rate on real estate price is weakened, but it is still negative.

\section{2) Variance decomposition}

It can be seen from Figure 4 and Figure 5 that the contribution rate of the change of money supply to the change of real estate price is similar to the contribution rate of the change of interest rate to the change of real estate price, regardless of the contribution rate of the real estate industry itself. The contribution rate of money supply to real estate price is gradually increasing, from the

\section{Response of LNHP to Cholesky}

One S.D. LNRATE Innovation

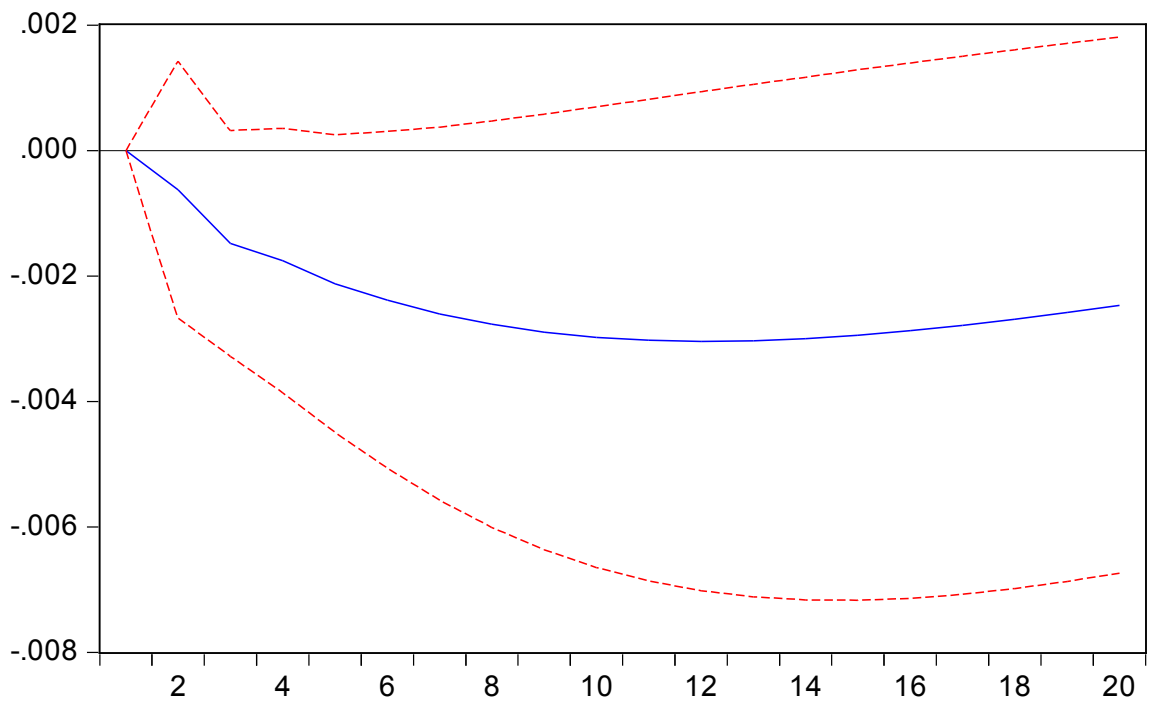

Figure 3. Pulse response diagram of LNHP to LNRATE.

Percent LNHP variance due to LNM2

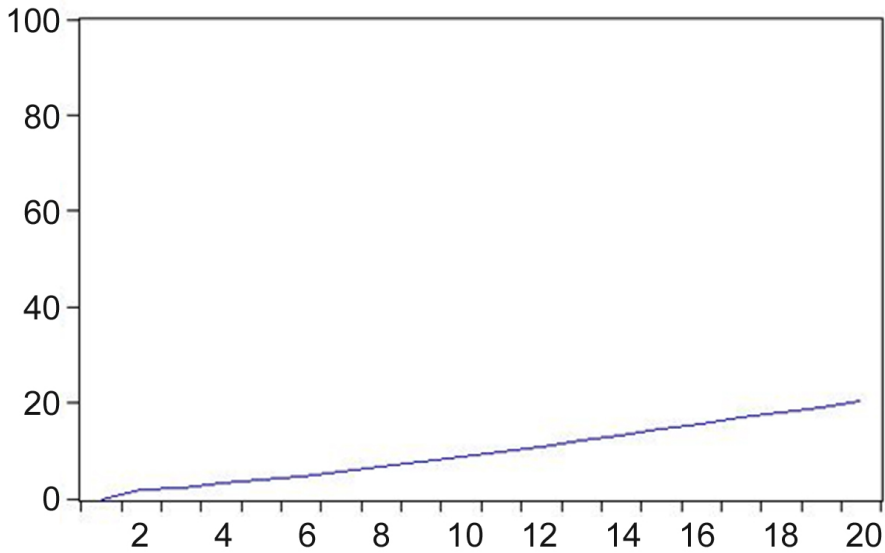

Figure 4. Contribution of M2 shock to real estate price change. 




Figure 5. Contribution of interest rate change shock to real estate price change.

current period to the fourth period, its contribution rate is relatively small, only about $3 \%$, then rises steadily, has already reached $20 \%$ to $20 \%$ period and still maintains the rising trend. The contribution of interest rates to real estate prices is not low, with a slow upward trend from the current period to the 20th, which levelled off at 16. In general, the impact of money supply and interest rates on real estate prices to contribute to the same.

\subsubsection{Empirical Analysis}

\section{1) An Empirical Analysis of the Effect of Money Supply on Real Estate Price}

The rapid rise of real estate prices in China in recent years is inseparable from the loose monetary environment in the financial market. Real estate industry is a capital-intensive industry, its development, investment and consumption need a lot of funds, and the rapid growth of money supply, to a certain extent, led to the rise of real estate prices. On the supply side, the increase in the money supply will bring a sufficient source of capital for real estate development. Real estate development enterprises can leverage the development and construction of a large project with the minimum amount of their own funds. Increase the supply of real estate market, help to curb the rise in real estate prices. On the demand side, the increase in the money supply has also given real estate investment, speculation and consumption an adequate source of capital-disposable income and credit funds, thereby increasing the demand for real estate, while our foreign exchange account has been increasing. Commercial banks' loanable funds are increasing, and the loans put into the real estate market are also increasing, thus increasing the effective demand of the real estate market and pushing up the real estate prices. In addition, the increase in the money supply will also push up the prices of raw materials and labor, increase the development costs of real estate, and push up the prices of real estate. From the result of impulse response, the effect of increasing money supply on demand and price increase is greater than that of increasing supply. In this way, the increase in the money supply to pro- 
mote the rise in real estate prices.

\section{2) An Empirical Analysis of the Effect of Interest Rate on Real Estate Price}

Interest rate is one of the most important economic levers in the market economy. In a mature real estate market, raising interest rates often has the effect of squeezing out asset price bubbles. As a result, in both the short and long term, raising interest rates has dampened real estate prices. On the demand side, higher loan rates have increased investors' investment and holding costs. It will also increase the amount of mortgage payments on homebuyers' homes, and the expected economic impact is beginning to show, leading to lower demand for homes. On the supply side, due to the increase in the cost of the use of funds for real estate development enterprises, the rising development costs of new projects will lead to the survival of the fittest, and the constant concentration of market suppliers will also decrease the scale of development. It then led to a fall in the supply of housing in the market one to two years later. In addition, higher interest rates will lead to increased financial pressure on developers to develop projects that could raise prices on the pretext of passing on costs, instead causing property prices to rise in the short term. From the result of pulse response, the effect of increasing interest rate on demand is more than that on supply. In this way, the increase in interest rates contributed to a fall in real estate prices.

\section{Conclusions and Policy Recommendations}

\subsection{Conclusions}

Through the above empirical analysis, we can find that monetary policy can control real estate prices. In a relatively long period of time, monetary policy variables and real estate prices have a stable relationship. In the short and long term, the interest rate is negatively correlated with the real estate price, which can effectively control the real estate price, and the time lag is relatively short. The effect of interest rate on the real estate price control is better and lasts for a long time. The money supply is positively related to the real estate price, that is, the increase of the money supply will lead to the rise of the real estate price. In the short term, the real estate price can be adjusted through the money supply and get better results, with a short time lag.

In general, China's monetary policy on real estate prices has a certain regulatory role. In the past two years, the country has frequently adjusted its monetary policy, hoping to control the problems of investment overheating in the macro economy through the use of monetary policy levers. Through the policy of interest rate, money supply and deposit reserve, the "three arrows" have developed simultaneously to control the problem of investment growing too fast and house prices rising too fast. Through the empirical test and analysis in this paper, it is proved that monetary policy can control house prices to a certain extent, but due to the lack of monetary policy itself regulation and control, the lack of monetary policy independence, the delay of monetary policy, the complexity of real estate market and the multi-subjectivity of decision influence lead to the difficulty of 
macro-control of monetary policy, and monetary policy is still unable to control the real estate price. The effect of real estate price regulation is not ideal, which is in line with the current situation in China.

\subsection{Policy Proposal}

According to the previous empirical analysis, money supply and real estate prices have a strong correlation, and the impact between them is positive, so we should pay more attention to M2 when we apply macro-control to the real estate market. With the development of our country's economy, the money supply increases, but the macroeconomic policy always has its advantages and disadvantages. Although the increase of the money supply stimulates the economic growth, it also causes the problem of excess liquidity. In particular, in 2008, the government implemented Plan 4 trillion to reduce the socio-economic impact of the global Golden Birthday crisis. Although these measures have played an extremely important role in maintaining the stable development of China's economy, due to the delay in monetary policy, the harm it has brought has become increasingly prominent, and the most prominent problem is the rise in asset prices. In particular, real estate prices are rising. Excessive issuance of money will drive up prices, stimulate house prices, and reduce residents' spending power and standard of living. Therefore, in the use of monetary policy to macro-control the economy, we should strictly and reasonably control the supply of money, to ensure that economic development is not simply blindly dependent on the promotion of money supply to promote.

At the same time, according to the empirical results, the interest rate can also have an impact on the real estate prices, and the impact is equal to that of the money supply. Therefore, the central bank should continue to promote the development of interest rate marketization in depth, and establish a benchmark interest rate based on the central bank. The money market interest rate is the intermediary, the perfect interest rate marketization mechanism determined by the market supply and demand. In addition, according to the housing level to increase a variety of mortgage interest rates, using interest rates to affect house prices. The central bank should consider a gradual transition from money supply to interest rates.

\section{Conflicts of Interest}

The author declares no conflicts of interest regarding the publication of this paper.

\section{References}

[1] Bjørnland, H.C. and Jacobsen, D.H. (2008) The Role of House Prices in the Monetary Policy Transmission Mechanism in Small Open Economies. Journal of Financial Stability, 6, 218-229. https://doi.org/10.1016/j.jfs.2010.02.001

[2] Mishkin, F.S. (2007) Housing and the Monetary Transmission Mechanism. NBER Working Papers, 11, 359-413. https://doi.org/10.3386/w13518 
[3] Elbourne, A. (2008) The UK Housing Market and the Monetary Policy Transmission Mechanism: An SVAR Approach. Journal of Housing Economics, 17, 65-87. https://doi.org/10.1016/j.jhe.2007.09.002

[4] Abraham, J.M. and Hendershott, P.H. (1994) Bubbles in Metropolitan Housing Market. NBER Working Papers, 7, 171-192. https://doi.org/10.3386/w4774

[5] Iwayama, N., Akiyama, K. and Ishigaki, K. (2003) Houses as Collateral: Has the Link between Houses Prices and Consumption in the U.K. Changed? Economic Policy Review, 8, 163-177.

[6] Ho, L.S., Wong, G. and Tse, R.Y.C. (2003) Privatization of Public Housing: How It Caused a Deep Recession in Hong Kong. Education in Hong Kong, 23, 23-62.

[7] Iacoviello, M. and Minetti, R. (2003) Financial Liberalization and the Sensitivity of House Prices to Monetary Policy: Theory and Evidence. The Manchester School, 71, 15. https://doi.org/10.1111/1467-9957.00332

[8] Giuliodori, M. (2005) The Role of House Prices in the Monetary Transmission Mechanism across European Countries. Scottish Journal of Political Economy, 52, 25. https://doi.org/10.1111/j.1467-9485.2005.00354.x

[9] Semlali, A.S. and Collyns, C. (2002) Lending Booms, Real Estate Bubbles, and the Asian Crisis. IMF Working Papers, 2.

[10] Iacoviello, M. and Minetti, R. (2008) The Credit Channel of Monetary Policy: Evidence from the Housing Market. Journal of Macroeconomics, 30, 69-96. https://doi.org/10.1016/j.jmacro.2006.12.001

[11] Davis, E.P. and Zhu, H. (2011) Bank Lending and Commercial Property Cycles: Some Cross-Country Evidence. Journal of International Money \& Finance, 30, 1-21. https://doi.org/10.1016/j.jimonfin.2010.06.005

[12] Titman, Q.S. (1997) Commercial Real Estate Prices and Stock Market Returns: An International Analysis. Financial Analysts Journal, 53, 21-34. https://doi.org/10.2469/faj.v53.n3.2082

[13] Wilson, P.J. and Okunev, J. (2010) Using Nonlinear Tests to Examine Integration between Real Estate and Stock Markets. Real Estate Economics, 25, 487-503.

[14] Chen, N.K. (2002) Asset Price Fluctuations in Taiwan: Evidence from Stock and Real Estate Prices 1973 to 1992. Journal of Asian Economics, 12, 215-232. https://doi.org/10.1016/S1049-0078(01)00083-5

[15] Meng, X. (2004) Monetary Policy Transmission in Housing Market. Zhejiang Finance, No. Z1, 22-23.

[16] Zheng, L.A.N. (2006) The Study of the Monetary Policy Transmission Effect of the Real Estate Market Based on the VAR Model. Hunan University, Changsha.

[17] Wang, J.C., Cao, J. and Ye, F.Q. (2010) Effectiveness Analysis of Monetary Policy Transmission Mechanism Based on State Space Model. Soft Science, 24, 44-47.

[18] Xie, J.R. (2002) Real Estate Bubble and Financial Crisis. Economic Management Press, Beijing, 23-26.

[19] Pi, S. and Wu, K.P. (2004) Causality between the Development of Real Estate Market and Economic Growth-An Empirical Analysis of China. Management Review, 16, 8-12.

[20] Zhang, X.R. (2012) Empirical Research on the Impact of Monetary Policy on Fixed Asset Investment. Times Finance, No. 3, 71.

[21] Chen, H. and Zheng, X. (2005) Economic Background of Interest Rate Policy Adjustment and Its Impact on Real Estate Market. New Finance, No. 3, 3-6. 
[22] Gong, B.N. (2013) Transmission Mechanism of Monetary Policy: Theoretical Development and Realistic Choice. Financial Review, No. 1, 20-43.

[23] Litterman, R.B. (1985) Forecasting with Bayesian Vector Autoregressions Four Years of Experience. Journal of Business \& Economic Statistics, 4, 25-38. 